\title{
Climate-disease connections: Rift Valley Fever in Kenya
}

\author{
Relações entre clima e doença: \\ febre do Vale do Rift, no Quênia
}

Assaf Anyamba 1

Kenneth J. Linthicum 2

Compton J. Tucker 3

\footnotetext{
1 NASA Goddard Space Flight Center, Code 923. Greenbelt, $M D, 20771$ USA.

2 Department of Defense (DoD) - Global Emerging Infections System, Division of Preventive Medicine, Walter Reed Army Institute of Research. Washington DC, 20307-5100 USA.

3 Earth Sciences Directorate NASA Goddard Space Flight Center, Code 923, Greenbelt, $M D, 20771$ USA.
}

Abstract All known Rift Valley fever(RVF) outbreaks in Kenya from 1950 to 1998 followed periods of abnormally high rainfall. On an interannual scale, periods of above normal rainfall in East Africa are associated with the warm phase of the El Niño/Southern Oscillation (ENSO) phenomenon. Anomalous rainfall floods mosquito-breeding habitats called dambos, which contain transovarially infected mosquito eggs. The eggs hatch Aedes mosquitoes that transmit the RVF virus preferentially to livestock and to humans as well. Analysis of historical data on RVF outbreaks and indicators of ENSO (including Pacific and Indian Ocean sea surface temperatures and the Southern Oscillation Index) indicates that more than three quarters of the RVF outbreaks have occurred during warm ENSO event periods. Mapping of ecological conditions using satellite normalized difference vegetation index (NDVI) data show that areas where outbreaks have occurred during the satellite recording period (1981-1998) show anomalous positive departures in vegetation greenness, an indicator of above-normal precipitation. This is particularly observed in arid areas of East Africa, which are predominantly impacted by this disease. These results indicate a close association between interannual climate variability and RVF outbreaks in Kenya.

Key words Rift Valley Fever; Disease Outbreaks; Aedes; Insect Vectors; Ecosystem

Resumo Entre 1950 e 1998 houve surtos de febre no Vale do Rift, no Quênia, após períodos de aumentos pluviométricos anormais. Em escala interanual, esses períodos estiveram associados à fase quente do fenômeno ENSO (El Niño/Southern Oscillation) na África Oriental. As chuvas alagam os criadouros de mosquitos - dambos -, cujos ovos, infectados pela via transovariana, eclodem, produzindo mosquitos Aedes, transmissores do vírus da febre do Vale do Rift aos seres humanos e, em especial, ao gado. A análise dos dados históricos sobre surtos de febre do Vale do Rift e indicadores do fenômeno ENSO - incluindo temperaturas superficiais dos Oceanos Pacífico e Índico e o Índice de Oscilação Sul-mostrou que mais de 75\% dos surtos ocorreram em períodos quentes do ENSO. Na época estudada - 1981-1998 -, o mapeamento das condições ecológicas via satélite (NDVI) - com dados normalizados sobre diferenças na vegetação - evidenciou que as áreas de surto apresentaram desvios anômalos na intensidade do verde da vegetação (indicador de pluviosidade alta), em particular, nas regiões áridas da África Oriental - as mais afetadas pela febre. Os resultados indicam associação estreita entre variabilidade climática interanual e surtos de febre do Vale do Rift no Quênia.

Palavras-chave Febre do Vale do Rift; Surtos de Doenças; Aedes; Insetos Vetores; Ecossistema 


\section{Background}

In the last twenty years there has been increased scientific interest in the connection between global climatic anomalies and disease outbreaks (Nicholls, 1991). Rift Valley fever (RVF), caused by a virus in the genus Phlebovirus, is one such example of a disease whose outbreaks have been shown to be closely coupled with climate anomalies (Davies et al., 1985). In Kenya, RVF primarily affects inhabitants of the dry lands of the Rift Valley system and the outlying semi-arid and arid grazing lands (Figure 1). RVF was first recognized in Kenya (Daubney et al., 1931) in the 1930s as an epizootic on a farm in Naivasha, killing several hundred sheep. There have been subsequent known outbreaks in most countries of sub-Saharan Africa including Sudan, Egypt, Mauritania, and parts of Southern Africa.

The virus that causes RVF is carried in the eggs of Aedes mosquitoes. These mosquitoes breed in isolated depressions called dambos found in these vast grassland areas (Figure 2). When the dambos flood during periods of extensive and widespread rainfall (Linthicum et al., 1983, 1984) the eggs of the Aedes mosquitoes hatch and the subsequent adults transmit the virus to domestic animals including sheep, goats, cattle, camels, and buffalo. These depressions also serve as good habitats for Culex mosquito species. When Aedes mosquitoes infect domestic animals with RVF, virus amplification occurs in these vertebrate hosts, leading to propagation into various Culex species that are capable of transmitting the virus to a wider area beyond the area of the original outbreaks (McIntosh, 1972).

\section{Climate connections: the role of EI Niño/Southern Oscillation}

Most of the semi-arid and arid lands of Kenya receive less that $700 \mathrm{~mm}$ of rainfall per year. Periodic widespread and heavy rainfall leads to extensive and widespread flooding. Above-normal rainfall in East Africa is now known to be teleconnected to the El Niño/Southern Oscillation (ENSO) phenomenon, the dominant climatic mechanism that drives global interannual climatic variability (Ropelewski \& Halpert, 1987). ENSO is exemplified by extensive warming of the normally cold waters of the central and eastern Pacific Ocean and a cooling in the western Pacific Ocean (Rasmusson \& Carpenter, 1982). El Niño (EN) is the term used to describe this periodic warming. The inhabitants of the Peruvian coast noticed the appearance of this phenomena around Christmas time, hence the name "El Niño", in reference to the Christ-child (Enfield, 1993).

The Southern Oscillation (SO) is the atmospheric counterpart to El Niño. The SO describes the large-scale atmospheric seesaw pattern between the western and eastern Pacific basins that drives the wind systems and ultimately precipitation patterns (Diaz \& Kiladis, 1993). Given the sheer size of the Pacific ocean basin, the dramatic change in the thermal east-west gradient of the sea surface temperatures results in the displacement and shifts in the normal zonal atmosphere-ocean circulation patterns (the so-called "Walker Circulation" or SO) in the global tropics. Sometimes the effects of these atmospheric circulation shifts extend into the subtropical Northern Hemisphere. These changes in the tropical ocean-atmosphere moisture energetics leads to anomalous climatic conditions, in particular dramatic shifts in precipitation patterns. Regions that are typically dry receive above-normal rainfall (eastern $\mathrm{Pa}$ cific), and those that are typically wet (Indonesian Basin) experience drought conditions during El Niño.

In Africa, the most dramatic manifestation of these shifts in rainfall patterns is illustrated by above-normal rainfall over a large area of equatorial Eastern African, particularly semiarid areas of Kenya, Somali, and Ethiopia and droughts over a large area of Southern Africa (Nicholson \& Entekhabi, 1986; Diaz \& Kiladis, 1993). The rainfall over East Africa at times persists for several months, as was observed during the 1997-1998 ENSO warm event, and results in extensive flooding over most of East Africa (Bell \& Halpert, 1998). Flooding of dryland dambo areas leads to the emergence of a large number of mosquitoes that transmit various types of diseases, including RVF.

\section{Satellite monitoring of eco-climatic conditions of RVF}

Satellite remote sensing can now monitor the eco-climatic conditions that lead to RVF outbreaks. Since most of the areas that are affected by RVF have poor and/or sparse coverage by conventional ground climate stations, remote sensing offers a rapid and comprehensive way of monitoring ecological conditions in these areas. Satellite monitoring since the early 1980s has made it possible to monitor vegetation conditions on a continental scale for Africa (Tucker, 1996). Research has shown that satel- 
RVF primarily affects domestic animals, especially cattle and sheep. Such domestic animals provide a pathway for transmission of the virus to pastoral people who depend on cattle for their livelihood.

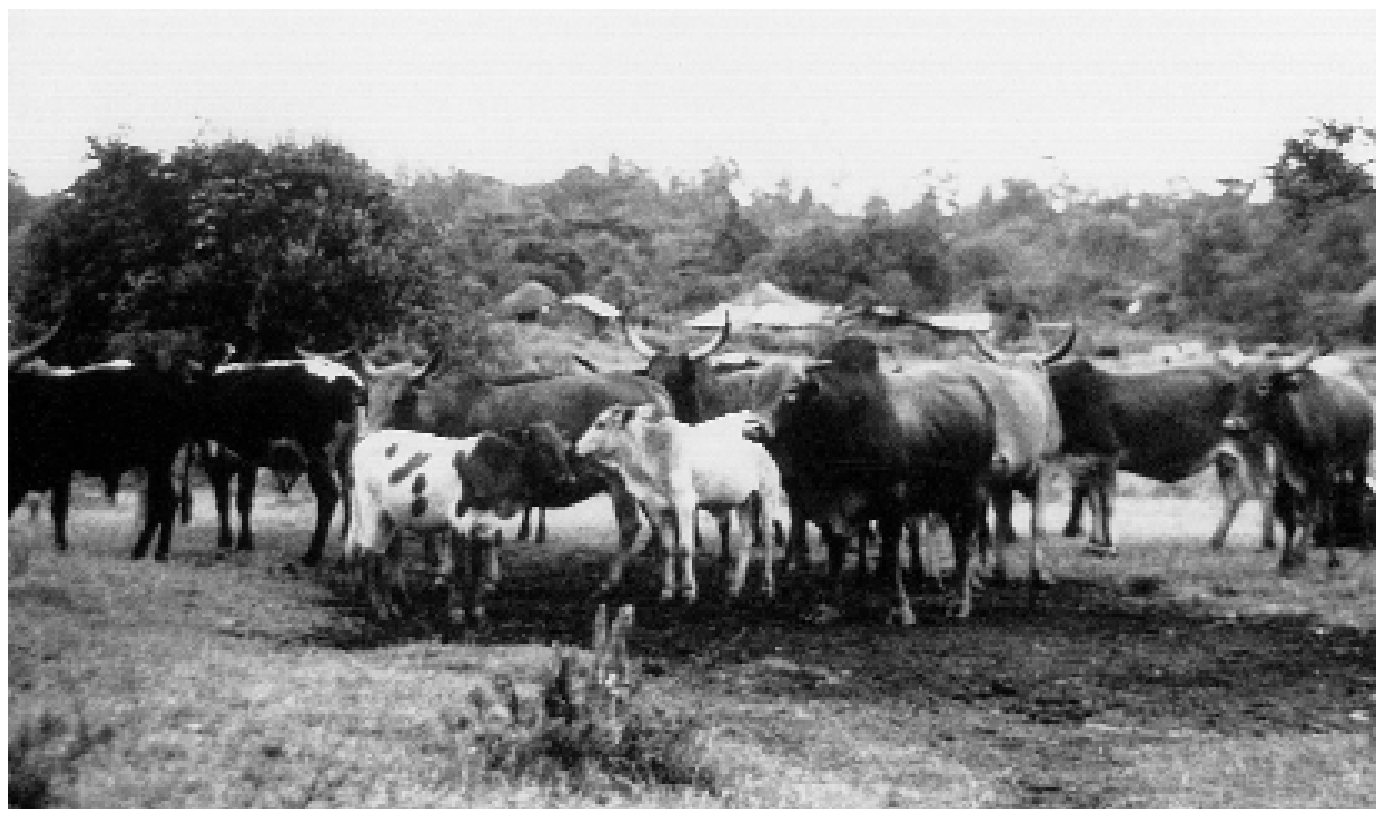

Figure 2

Flooded dambo in a grassland plateau area of Eastern Kenya. Such grassland depressions (dambos) lood during periods of above normal rainfall and serve as good habitats for the breeding of Aedes mosquitoes that carry the RVF virus.

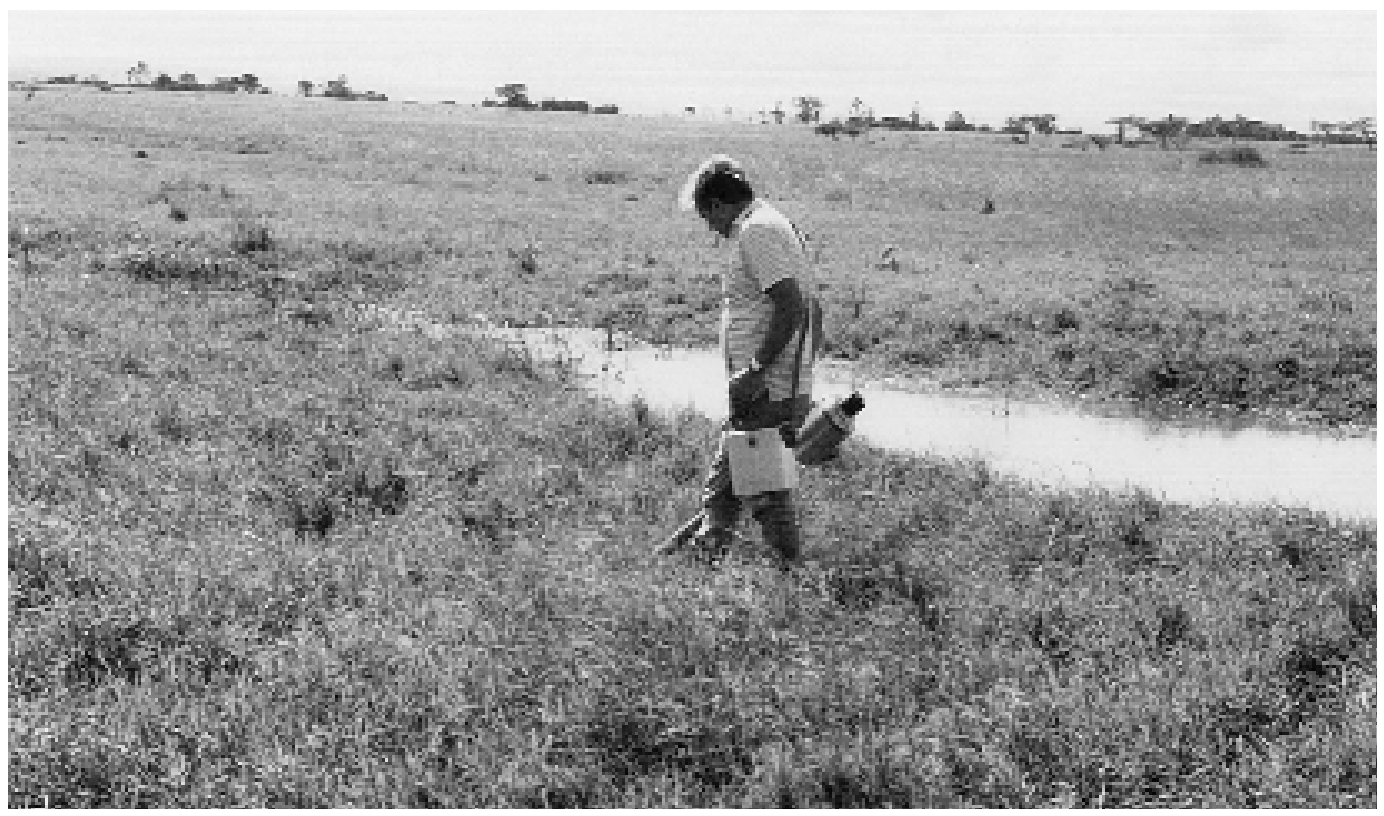


lite measurements of vegetation conditions expressed in the form of the normalized difference vegetation index (NDVI) are strongly correlated with rainfall in semi-arid areas of Africa receiving less than $800 \mathrm{~mm}$ of rainfall (Nicholson et al., 1990; Tucker \& Nicholson, 1999). Therefore, NDVI can be used as a surrogate for rainfall and also an expression of spatial and temporal ecological dynamics in arid and semi-arid areas (Justice et al., 1986; Nicholson et al., 1990). The daily sampling that is possible using the National Oceanographic and Atmospheric Administration (NOAA) series of orbiting satellite from which NDVI data are derived means that vegetation response to precipitation in semi-arid areas can be rapidly monitored. In order to minimize cloud contamination, the data are composited into 10-day and monthly time frames (Holben, 1986). The 20+year record of these measurements currently available is making it possible to study ecologically coupled diseases in relation to interannual climate variability patterns. The spatio-temporal anomaly record of the measurements can illustrate for specific locations the biorhythms of conditions that trigger outbreaks of diseases.

In addition to NDVI, measurements of cloudiness in the form of Outgoing Longwave Radiation (OLR) can be used to infer precipitation patterns over the global tropics (Climate Diagnostics Center, 2000). Persistent cloudiness is an important factor in the survival of adult mosquitoes and propagated virus epizootics (Sellers et al., 1982). Measurements of sea surface temperatures (SST) that drive tropical convection and moisture transport can also be derived from the NOAA satellites from which NDVI and OLR measurements are derived (Reynolds \& Smith, 1994). In total, the availability of these three satellite data sets represents the complete cycle of ocean-atmosphere-land coupling that determines habitat conditions for the survival and propagation of the RVF virus. Therefore, understanding the spatial and temporal changes in the anomaly patterns of these measurements can enable us to identify areas that are vulnerable to climate anomalies that may create conditions necessary for disease outbreaks.

\section{Outbreaks of RVF in relation to ENSO: past and present}

RVF outbreaks are known to follow periods of abnormally high rainfall in Eastern Africa (Linthicum et al., 1983, 1984; Davies et al., 1985). Past studies indicate that periods of above-nor- mal rainfall in Equatorial Eastern Africa are associated with warm El Niño/Southern Oscillation (ENSO) events (Ropelewski \& Halpert, 1987, 1989). The Southern Oscillation Index (SOI) is the most commonly used index used to represent the different phases of the ENSO phenomenon (Chagas \& Puppi, 1986; Glantz, 1991). This index compares atmospheric pressure in Papeete, Tahiti (east Pacific) to that of Darwin, Australia (west Pacific). Strong negative anomalies are associated with an "El Niño" event, and strong positive departures of the index are associated with "La Niña" conditions (Cane, 1986; Rasmusson, 1991). Plotting this index against historical outbreaks of RVF (Figure 3) shows that a large number of known outbreaks have occurred during the negative phase of the SOI (Linthicum et al., 1999). Since the early 1950s, there have been eight periods with RVF viral activity and 13 periods when there were strong negative anomalies in the SOI $(<-1.5)$. RVF epizootics in 1951-1953, 1961-1963, 19681969, 1977-1979, and 1997-1998 (Davies et al., 1985) followed periods of exceptionally abovenormal regional rainfall. In late 1957 and 1982 and mid-1989, heavy rainfall in Kenya preceded RVF virus activity that was detected by either identification of clinical cases, isolation of the virus in mosquitoes, or detection of high levels of immune globulin (type IgM) antibody specific for RVF virus, indicating recent RVF infection in domestic animals and humans (Davies et al., 1985; Linthicum et al., 1987; Logan et al., 1991). Although RVF and above-normal rainfall always followed periods of strong negative deviation of the SOI, neither the strength nor the length of the SOI anomaly correlated with intensity of RVF activity. For example, regional RVF activity detected in 1982 and 1998 followed an intense SOI anomaly < -3, while the major outbreaks starting in 1951, 1961, and 1968 occurred after SOI anomalies $<-2$. Strong negative SOI anomalies also occurred in 1964, 1969, 1972-1973, 1981, and 1991-1995; however, there was neither abovenormal rainfall nor detectable RVF activity in Kenya for these periods. Our recent studies indicate that the overall ability to predict an RVF outbreak using SOI anomalies alone was only $67 \%$, indicating other factors must be involved.

Taking into consideration SST departure patterns, concurrent Pacific and Western Indian Ocean (WIO) SST anomalies $>3^{\circ} \mathrm{C}$ and $0.5^{\circ} \mathrm{C}$, respectively, are strongly correlated with widespread rains in East Africa (Myneni et al., 1995; Nicholson \& Kim, 1997) and RVF outbreaks (Figure 4). For example, RVF activity followed by 2 (1982-1983) and 5 (1997-1998) months of 
Time series plot of SOI anomalies from 1950 to May 1998. Periods of RVF activity in Kenya are depicted as thick black bars.

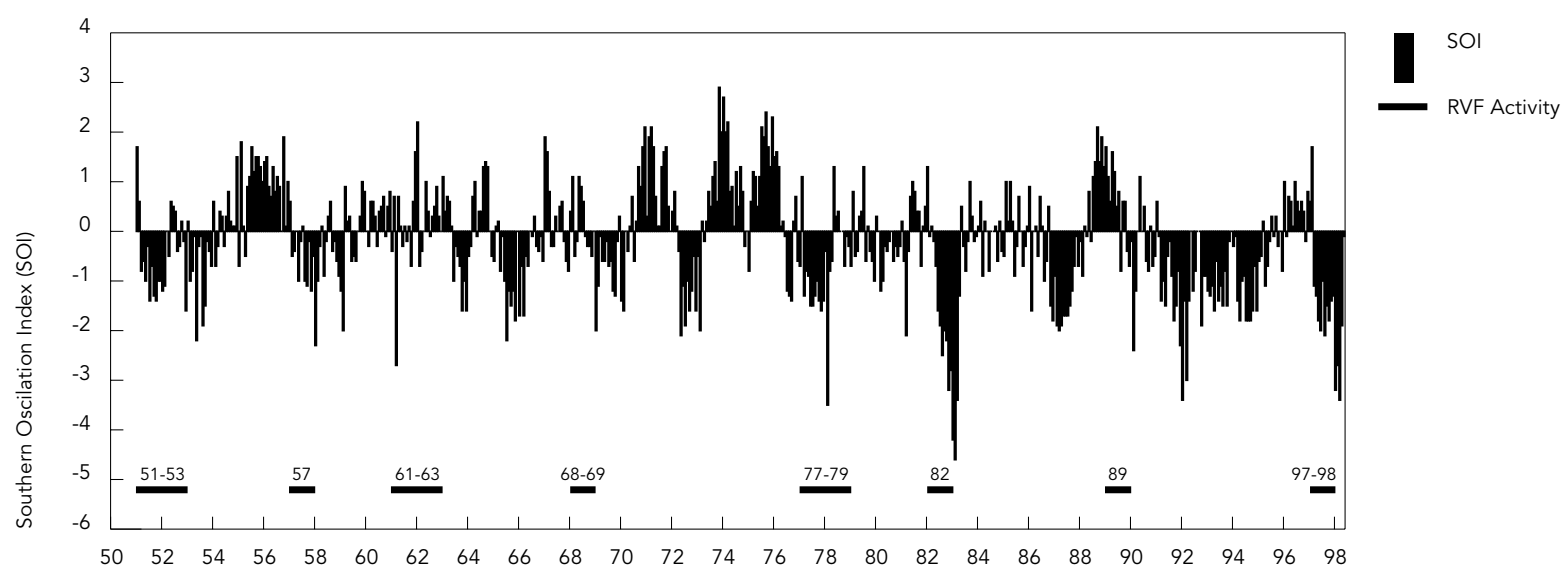

* Note that in most of these cases, outbreaks occurred during periods of the negative phase of the SOI.

Figure 4

Plot of Western Indian Ocean (WIO) and equatorial eastern Pacific sea surface temperature (SST) anomalies from January 1982 to May 1998

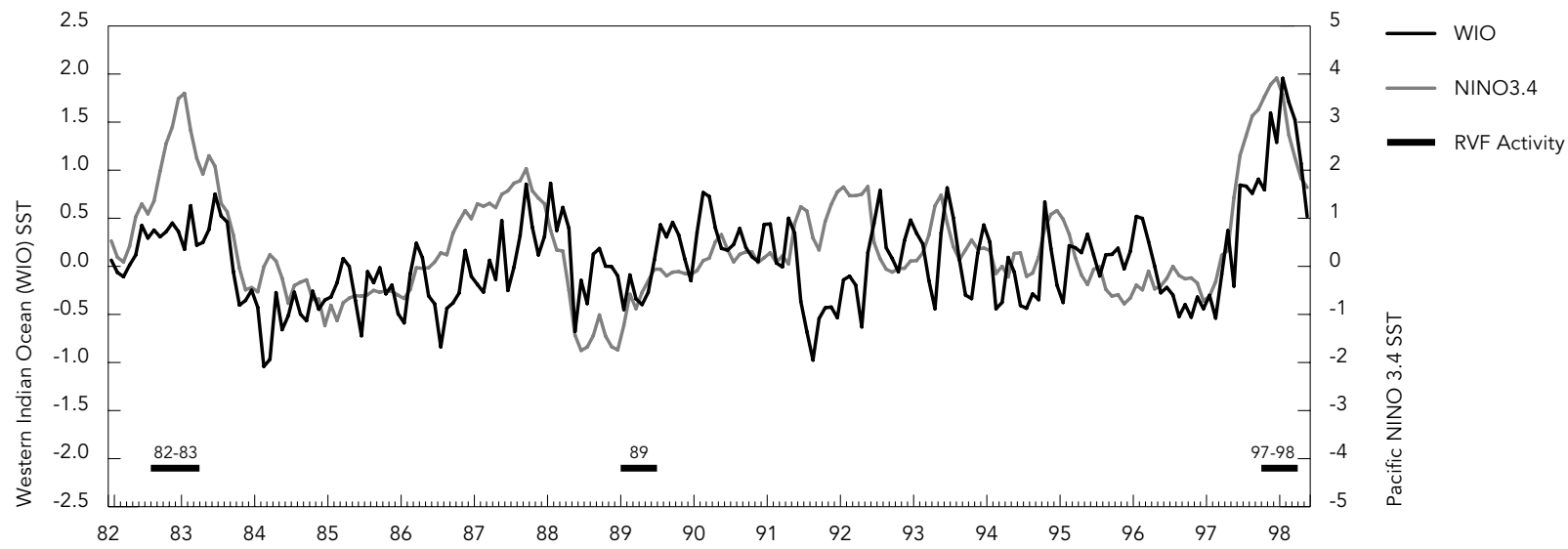

* Note that large-scale outbreaks of RVF have occurred when both WIO and Pacific SST are simultaneously elevated as in 1982/83 and 1997/98. The outbreak in 1989 was localized rather than regional (Linthicum et al., 1999). Although a warm ENSO event occurred in the Pacific in 1991/92, the WIO region had below normal SSTs, and there was no RVF activity identified in Kenya. 
strong positive concurrent equatorial Pacific and WIO SST anomalies. When both equatorial Pacific and WIO SSTs have strong positive departures, the extent of the WIO temperature anomaly was indicative of the intensity and duration of RVF activity. However, when the strength of the concurrent Pacific and Indian Ocean SST anomalies is reduced, but still positive, the pattern of increased rainfall can be irregular and a region-wide RVF effect cannot usually be found, as was the case in 1989 .

In order to determine the extent and location of likely RVF outbreaks in years lacking concurrently high Pacific and WIO SST anomalies, NDVI data derived from NOAA satellites can be used to identify areas of abnormally high green vegetation development resulting from above-normal rainfall (Anyamba \& Eastman, 1996; Myneni et al., 1995). For example, during the 1997-1998 warm event, strong positive NDVI anomalies were observed for East Africa starting in October 1997 (the start of the normal short rainy period) extended to March and April 1998 (through the normal dry season of December-February) (Figure 5). NDVI anomalies were significantly correlated with RVF activity 1 to 2 months before detection of viral activity $(\mathrm{p}<0.5)$. Strong NDVI positive anomalies were observed in June 1989 with the presence of RVF activity, and in January-February 1993, in the absence of detectable RVF activity (Fig- ure 5). We suggest that these elevated NDVI values at these times reflected local rain conditions rather than regional patterns. We suggest that NOAA AVHRR normalized difference vegetation index time-series data are required to identify more localized areas where anomalous rainfall has occurred and hence more localized RVF activity is likely to be present. An observation of persistence of greener than normal conditions can provide ground surveillance teams with the basic information about areas to be monitored for RVF activity.

Based on the combined climate and satellite vegetation data, it is shown that regional RVF virus activity in Kenya can forecast NDVI 2-5 months before outbreaks occur (Linthicum et al., 1999). Such advance knowledge can permit vaccination of domestic animals and pretreatment of mosquito habitats adjacent to domestic animal herds and human dwellings with highly effective sustained-release insecticides that would be released upon flooding (Logan et al., 1991).

\section{Summary and societal implications}

Rift Valley fever is a good example of a disease that is well coupled with climatic anomalies. The ability to forecast these ENSO events almost a year in advance means that we can in

Figure 5

Plot of Western Indian Ocean SST anomalies against NDVI anomalies for Naivasha with periods of RVF activity

depicted as think black bars.

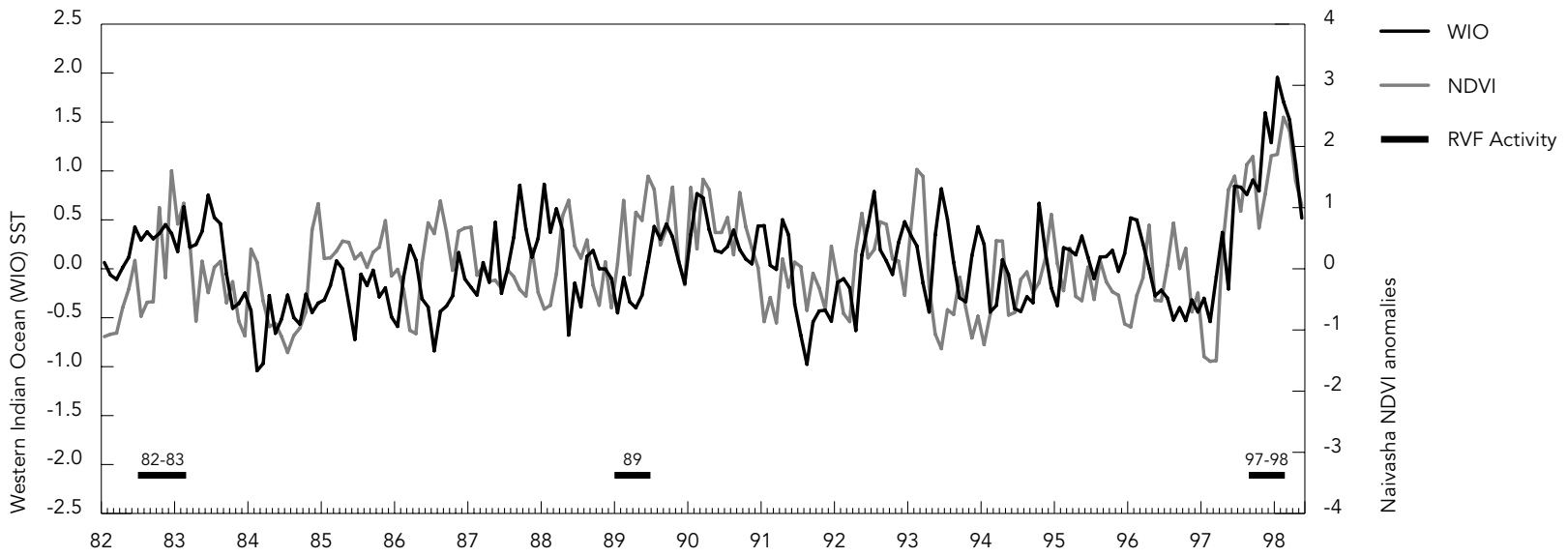

* Note that periods of above normal SST (1982/83 and 1997/98) also show above normal NDVI persisting

for several months, indicating above normal rainfall during these periods. 
principle anticipate with some level of confidence the areas that are likely to be impacted. This provides a valuable lead-time to take measures to reduce negative societal impacts of ENSO on health and economic well-being. Livestock is the main source and in some cases the only source of livelihood and cash economy in the semi-arid and arid parts of Kenya. The death of large herds of livestock from RVF and other livestock-related diseases and flooding destroys the local economy. During the 1997-1998 ENSO event, the Gulf Arab countries banned the importation of livestock products from East Africa due to the fear of spreading RVF to humans in the these countries. This ban, enforced for almost a year, resulted in a loss of foreign exchange earnings to Kenya, Somalia, and Ethiopia, and in effect jeopardized the domestic economy and the livelihoods of pastoral farmers. In addition, it takes many years to restock and build productive livestock herds to generate market value. The occurrence of RVF may and does perpetuate poverty conditions for several years in these areas. Pastoral farmers are forced to take loans from the respective governments to buy livestock. It often takes a long time to pay back these loans.

The effects of RVF outbreaks are compounded by outbreaks of other diseases, including malaria and cholera. The ENSO event of 19971998 left hundreds of people dead, primarily from multiple-disease outbreaks. It should however be noted that the high mortality rate in these semi-arid areas to a large extent was amplified by the lack of adequate and quality primary health care facilities. Over the last several years primary health care facilities have either deteriorated or failed to improve. In most cases the people have to travel long distances to reach these facilities. Those facilities that still exist cannot cope with large numbers of patients during epidemic periods due to lack of medicines and room to accommodate the flood of patients. Furthermore, given the fact that RVF is an episodic disease, the pharmaceutical industry has not found this to be an economically viable endeavor for which to develop drugs. As a consequence there are no commercially available off-the-shelf drugs to treat cases of RVF.

\section{Acknowledgments}

The results presented in this paper are part of collaborative research between NASA's Goddard Space Flight Center - Earth Sciences Directorate's Human Health Initiative and Walter Reed Army Institute for Research (WRAIR) contribution to the Department of Defense, Global Emerging Infections System.

\section{References}

ANYAMBA, A. \& EASTMAN, J. R., 1996. Interannual variability of NDVI over Africa and its relationship to El Niño/Southern Oscillation. International Journal of Remote Sensing, 17:2533-2548.

BELL, G. D. \& HALPERT, M. H., 1998. Climate Assessment for 1997. Bulletin of American Meteorological Society, 79:1-50.

CANE, M. A., 1986. El Niño. Annual Review of Earth and Planetary Sciences, 14:43-70.

CHAGAS, C. \& PUPPI, G., 1986. Introduction. In: Persistent Meteo-Oceanographic Anomalies and Teleconnections (C. Chagas \& G. Puppi, eds.), pp. 115, Citta del Vaticano: Pontifica Academia Scientiarvm. 
CLIMATE DIAGNOSTICS CENTER, 2000. <http://www. cdc.noaa.gov/ map/maproom/text/climate_ products.shtml>.

DAVIES, F. G.; LINTHICUM, K. J. \& JAMES, A. D., 1985. Rainfall and epizootic Rift Valley ever. Bulletin of the World Health Organization, 63:941-943.

DAUBNEY, R.; HUDSON, J. R. \& GRAHAM, P. C., 1931. Epizootic hepatitis or Rift Valley fever: An undescribed virus disease of sheep, cattle and man from East Africa. Journal of Pathology and Bacteriology, 34:545-549.

DIAZ, H. F. \& KILADIS, G. N., 1993. Atmospheric teleconnections associated with the extreme phases of the Southern Oscillation. In: El Niño: Historical and Paleoclimatic Aspects of the Southern Oscillation (H. F. Diaz \& V. Markgraf, eds.), pp. 7-28, New York: Cambridge University Press.

ENFIELD, D. B., 1993. Historical and prehistorical overview of El Niño/Southern Oscillation. In: El Niño: Historical and Paleoclimatic Aspects of the Southern Oscillation (H. F. Diaz and V. Markgraf, eds.), pp. 95-118, New York: Cambridge University Press.

GLANTZ, M. H., 1991. Introduction. In: Teleconnections Linking Worldwide Climate Anomalies $(\mathrm{M}$ H. Glantz, R. W. Katz \& N. Nicholls, eds.), pp.1-12, New York: Cambridge University Press.

HOLBEN, B. N., 1986. Characteristics of maximumvalue composite images from temporal AVHRR data. International Journal of Remote Sensing, 7:1417-1434.

JUSTICE, C. O.; HOLBEN, B. N. \& GWYNNE, M. D., 1986. Monitoring East African vegetation using AVHRR data. International Journal of Remote Sensing, 7:1453-1474.

LINTHICUM, K. J.; DAVIES, F. G.; BAILEY, C. L. \& KAIRO, A., 1983. Mosquito species succession dambo in an East African forest. Mosquito News, 43:464-470.

LINTHICUM, K. J.; DAVIES, F. G.; BAILEY, C. L. \& KAIRO, A., 1984. Mosquito species encountered in a flooded grassland dambo in Kenya. Mosquito News, 44:228-232.

LINTHICUM, K. J.; BAILEY, C. L.; DAVIES, F. G. \& TUCKER, C. J., 1987. Detection of Rift Valley fever viral activity in Kenya by satellite remote sensing imagery. Science, 235:1656-1659.

LINTHICUM, K. J.; ANYAMBA, A.; TUCKER, C. J.; KELLEY, P. W.; MYERS, M. F. \& PETERS, C. J., 1999. Climate and satellite indicators to forecast Rift Valley fever epidemics in Kenya. Science, 285:397400.

LOGAN, T. M.; LINTHICUM, K. J.; DAVIES, F. G.; BINEPAL, Y. S. \& ROBERTS, C. R., 1991. Isolation of Rift Valley fever virus from mosquitoes (Diptera: Culicidae) collected during an outbreak in domestic animals in Kenya. Journal of Medical Entomology, 28:293-295.

McINTOSH, B. M., 1972. Rift Valley fever. 1. Vector studies in the field. Journal of the South Africa Veterinary Association, 43:391-395.

MYNENI, R. B.; LOS, S. O. \& TUCKER, C. J., 1995. Satellite-based identification of linked vegetation index and sea surface temperature anomaly areas from 1982-1990 for Africa, Australia, and South America. Geophysical Research Letters, 23:729-732.
NICHOLSON, S. E. \& ENTEKHABI, D., 1986. The quasi-periodic behavior of rainfall variability in Africa and its relationship to the Southern Oscillation. Archive Fur Meteorologie Geophysik und Bioklimatologie, A 34:311-348.

NICHOLSON, S. E.; DAVENPORT, M. L. \& MALO, A. R., 1990. A comparison of vegetation response to rainfall in the Sahel and East Africa using normalized difference vegetation index from NOAAAVHRR. Climate Change, 17:209-241.

NICHOLSON, S. E. \& KIM, J. Y., 1997. The relationship between El Niño-Southern Oscillation and African rainfall. International Journal of Climatology, 17:117-135.

NICHOLLS, N., 1991. Teleconnections and health In: Teleconnections Linking Worldwide Climate Anomalies (M. H. Glantz, R. W. Katz \& N. Nicholls, eds.), pp. 493-510, New York: Cambridge University Press.

RASMUSSON, E. M. \& CARPENTER, T. H., 1982. Variations in tropical sea surface temperature and surface wind fields associated with Southern Oscillation/El Niño. Monthly Weather Review, 110: 354-384.

RASMUSSON, E. M., 1991. Observational aspects of ENSO cycle teleconnections. In: Teleconnections Linking Worldwide Climate Anomalies (H. F. Diaz \& V. Markgraf, eds.), pp. 309-343, New York: Cambridge University Press.

REYNOLDS, R. W. \& SMITH, T. M., 1994 Improved global sea surface temperature analyses. Journal of Climate, 7:929-948.

ROPELEWSKI, C. F. \& HALPERT, M. S., 1987. Global and regional scale precipitation patterns associated with El Niño/Southern Oscillation. Monthly Weather Review, 115:1606-1626.

ROPELEWSKI, C. F. \& HALPERT, M. S., 1989. Precipitation patterns associated with the high-index phase of the Southern Oscillation. Journal of Climate, 2:268-284.

SELLERS, R. F; PEDGLEY, D. E. \& TUCKER, M. R., 1982. Rift Valley fevers Egypt 1977: Disease spread by windborne insect vectors? Veterinary Record, 110:73-77.

TUCKER, C. J., 1996. History of the use of AVHRR data for land applications. In: Advances in the Use of NOAA-AVHRR Data for Land Applications (D. D'Souza, ed.), pp. 1-19, Dordrecht: Kluwer Academic Press.

TUCKER, C. J. \& NICHOLSON, S. E., 1999. Variations in the size of the Sahara Desert from 1980-1997. Ambio, 28:587-591. 